\title{
A Field Research On Youth's Brand Loyalty And Brand Sensitivity In Clothes: A Application in Turkey
}

\author{
Yakup Durmaz, Özlem Özer, and Sinan Çavuşoğlu
}

\begin{abstract}
The purpose of this study is to measure brand loyalty and brand sensitivity among high school students. The research sample was composed of 338 vocational high school students in a district of Southeastern Anatolia. Questionnaire was used as data collection tool in the study. The questionnaire included demographic factors, socio-cultural factors and psychological factors to measure brand loyalty and brand sensitivity. The collected data were analyzed with SPSS program. Findings have shown that there was no significant difference between men and women with both brand loyalty and brand sensitivity, and that education level of parents, families, peers and social class positively affected brand sensitivity. It has also been found that psychological factors had a positive effect on brand loyalty and brand sensitivity of young people.
\end{abstract}

Index Terms - Brand, Brand Loyalty, Brand Sensitivity

\section{INTRODUCTION}

Trade is of great importance in Turkey's technological and economic growth. In recent years great progress has been made in this direction. Businesses need to raise awareness so that they can take advantage of global markets. This awareness raises branding.

Brand is one of the most important factors of consumers' product preferences. Its features make a product special and this makes it to be preferred. Indeed, it is not easy to make it preferable. We are living in the age of technology. Consumers can reach the product they want at any time and place. Competition is on the rise because there is no limit between product and customer thanks to technological advances. Customers can easily reach product alternatives and evaluate the alternatives thanks to the Internet. On that account, companies give more importance and value to their brands. Consumers often have an emotional commitment to the brand. This link reveals the degree of commitment of the customer to the brand. This commitment gains continuity day by day. That is, brands have an important place in the choice of products. Products are preferred due to their effects on consumers. However, the important thing is to ensure continuity of this choice. In other words, it is very important to be able to create loyalty on customers.

While the product is a functional benefit, the brand is the sign that increases the value of that product. The product is produced and the brand is created. The brand is permanent while a product can change day by day. In short, the brand represents a product. The aim of marketing is to meet the wishes and needs of consumers. For this, the behaviors of consumers should be known. It is necessary to analyze the consumers - society well by doing a good AR-GE study. So it is necessary to understand what people buy, why they buy it and where they buy it. It is very difficult to respond to the needs without understanding this. Brand is an important part of a product. For this reason, brand affects people's purchasing behavior.

In fact, brands are similar to people. Brands also have parents as protectors just like people who have parents as protectors. It does not appear all of a sudden. An intensive work and effort is spent. A name suitable with the features of the product is found. They are advancing with the advice of those leading them to grow well. This hard work shows its results and they grow very quickly. They prove themselves and announce their names everywhere.

Families, friends and celebrities have significant effects on the purchasing behavior of young consumers. Especially in the early days of adolescence, young consumers are influenced by the people to whom they have role models while purchasing. In addition, due to technological developments, consumers can access the information they need whenever they want. This makes the business of marketers difficult because it is even harder to attract the attention of the customers. Young people spend enough time in their daily lives to dress up. In this context, the brand has an important place.

This study was conducted to analyze brand loyalty and brand sensitivities of female vocational and male high school students located in a district in the Southeast Anatolian region. This study is original because such kind of a study has not been conducted before in this region before

\section{BRAND CONCEPT}

The aim of marketing is to meet the needs of people. In order to meet this goal, it is first necessary to investigate where, how and why consumers buy goods and services. It is not possible to determine needs without knowing the consumers. That is to say, marketers must analyse and know target groups well. Consumer behaviour can be defined as the activities of

Published on March 21, 2020

Assoc. Prof. Dr. Yakup Durmaz, Hasan Kalyoncu University, Iktisadi

Idari ve Sosyal Bilimler Faculty, Gaziantep, Turkey.

(e-mail: yakup.durmaz@hku.edu.tr)

Lecturer Özlem Özer, Harran University, Turkey.

(e-mail: ozlemozer@harran.edu.tr )

Lecturer Dr. Sinan Çavuşoğlu, Bingöl University, Turkey.

(e-mail: sinankys42@gmail.com ) 
choosing, buying and disposing products and services. While marketers are directing consumers to products, consumers are choosing the ones best suited to their needs. The changing conditions day by day force consumers to choose brands instead of giving money to products because consumers are looking for the surplus value of brands compared to other products [10].

The rapid progress of technology and increasing consumer preferences have forced marketers to create new and different marketing tactics. Branding is one of them. Using a certain brand offers various advantages to consumers. The consumer sees brand as trust, prestige, price and quality. For businesses, brand refers to good sales. Good sales definitely bring high profits. As a result, we can understand that brand is money for businesses. A strong brand can easily provide customers on the market [27].

The search, which will separate the producer or the seller from each other in order to differentiate the products from the others, has caused the name 'brand' to be born. Brand was first seen as signs and symbols in ancient Egyptian bowls [9].The birth of the word branding is based on the fact that the villagers stamp the animals to separate them. This leads to animal differentiation. So, the brand means differentiation [2].

Brand is basically just a 'name' or a sign that is perceived in people's memory [6].In Turkish Language Society's current dictionary, brand is defined as a proper name which helps to present and distinguish a commercial commodity or object from the others [25]. For Yadin [26] brand is defined in a simple and narrow way with the personality and visual identity given to him by the proprietor, creator and owner of a product in advertising, marketing and marketing communications.

Brand consists of two approaches. The first is the traditional approach described as 'product addition'. Brand is primarily regarded as a descriptor. As a result, brand decision is one of the most recent decisions made during new product development processes typically found in textbooks. The second approach is the 'holistic' perspective. Beyond the product, this approach focuses on the brand itself as the only focus [3].

Ayhan [4] describes the existence of a brand as an image, brand and presentes quality in the way of brand building. He defines image as a fragile entity that is hard to recover; brand as a costly feature directly proportional to the image; quality as the vital fluid to reach image and brand.

Brands provide an integrated solution with the image they provide by guaranteeing quality. Branding is a process that goes beyond the specific components of the product and goes through the product as a whole [18]. A brand is a mechanism that provides competitive advantage for firms through differentiation. These differentiating qualities provide customer satisfaction and payment advantages [24]. The brand is so simple that consumers cannot physically differentiate from their competitors in memory. Many products have differentiated due to the strong brands that have emerged over the years. Some examples are coffee, bath soap, salt, beer, pickles, even water [13].

According to Article 5 of the Decree Law No. 556 on the Protection of Brands, a trademark, provided that it can distinguish/distinguishes the goods and services of one undertaking from the goods and services of other undertakings, may consist of all kinds of signs such as words, including personal names, designs, letters, numerals, the shape of the goods or (of) the packagings, capable of being represented graphically or by similarly descriptive means and capable of being published and reproduced by printing.

In terms of added value, the brand also includes the internal and external features of the product, the product's name as well as the advertising function. For this reason, the brand is the synthesis of physical, logical and emotional elements. These features should be distinguishing the brand from its competitors. Consumers are looking for a reason to prefer that brand to others. Consumers also pay attention to the suitability of the brands they prefer to their personality [20]. The characteristic feature of a successful brand is that it should be responding to psychological needs as well as meeting functional needs [11].

\section{A. Brand Loyalty and Brand Sensitivity}

Brand loyalty is considered as a random and deterministic approach in the literature and brand loyalty and brand sensitivity are related to different concepts. Some of these are consumer satisfaction, brand equity, learning, habits and interest [19]. Brand loyalty is a customer's commitment to a particular brand. This situation varies greatly and the brand may be complicated by the fluctuations in the manner of buying by loyal groups. Research, especially research, fantasy, and swings, can be determined so that marketing experts can decide on marketing and advertising investment programs with minimum risk [26].

If a brand is bought more than others, this is due to the loyalty to that brand. That is to say, brand loyalty means consistently preferring a brand more than the [12]. Brand loyalty is a measure of a customer's commitment to a brand. Indeed, brand loyalty means a consistent repurchase of a brand preferred by a consumer [15].

While the variables that reflect the characteristics of the brand are brand reputation, brand competence and brand expectation, the variables that reflect the interaction between the consumer and the brand are brand appreciation, brand experience, brand satisfaction, brand trust and friend group approval [7]. In fact, brand loyalty is a biased answer. This means that there must be a systematic tendency to buy a particular brand or brand group, and that the new brand selection should not follow the zero ordering process. This is a zero ordering process if each brand is selected by the consumer, with a certain probability, independent of the customer's past purchasing decisions [16].

The studies on brand loyalty in the literature and the topics addressed in the studies can be summarized as follows:

Ünal et al. [22] have conveyed theoretical information about personal values and brand loyalty in the first part of the article market segmentation in terms of brand loyalty and personal values. In the second part of the study, consumers are divided into subgroups in terms of their personal values and the reasons that are influential on brand loyalty. Although there are many studies in the literature which examine individual values and brand loyalty variables separately, it is decided that this study should be done because there is no study which examine these two together. 
In the study of Balıkçığlu and Oflazoğlu [5], the model has been tested that the self-brand image congruence was directly related to the brand evangelism and indirectly related to the brand loyalty. The self-brand image congruence and the effect of brand loyalty on the brand evangelism have been identified.

In their study about finding the effect of memory based experiences on loyalty of customers who visit green star hotels, Kement and Çavuşoğlu [14] have come to the conclusion that the entertainment and aesthetic perceptions of hotel customers affect the level of loyalty, but the dimension of education and escape does not affect customer loyalty.

Mırakçı [17] has investigate the impact of ready-made clothing brands on young people in intense competition in the KTÜ master thesis titled the effects of trust and satisfaction on brand loyalty. Factors affecting young people's buying behaviour have been discussed. It has been shown how these factors change with respect to personal and socio-economic characteristics. This study has been very helpful in seeing how young people are loyal to brands and influenced by brand characteristics under changing living conditions.

Yildiz [27] has grouped brand loyalty types as devoted buyers, brand-friendly buyers, customers satisfied with price change, satisfied-accustomed customers and brand loyalty in his master thesis titled determining the relation between youth's brand trust and loyalty.

Consumers do not tend to change the brands they use as long as they do not meet a specific reason. Brand image must be strengthened to create a new brand loyalty for such people. Consumers who really love their brand have a strong brand loyalty. The reason for the formation of this brand loyalty is the emotional relationship that consumers establish with the brand [12]. Consumers can buy a certain brand again and again, but without a high brand sensitivity this will only be a purchase inertia. In the case of purchase inertia, the consumer can not distinguish between brands and does not perceive significant differences between brands. Repeated purchases may be due to environmental constraints similar to the usual purchasing or product range. Only under strong brand sensitivities can a consumer be loyal to the brand [23]. Taylor et al. [21] stated that satisfaction, value, change resistance, effectiveness, trust and brand value are important elements in terms of customer loyalty.

Doğan [8] has investigated the relationship between consumers' brand trust and brand loyalty, and also investigated whether the brand trust and brand loyalty differed according to demographic characteristics of consumers in his master thesis titled the relationship between consumers' brand trust and brand loyalty.

\section{MATHODOLOGY}

\section{A. Research Model, Population and Sample}

Figure 1: Youth's Brand Loyalty and Brand Sensitivity Model

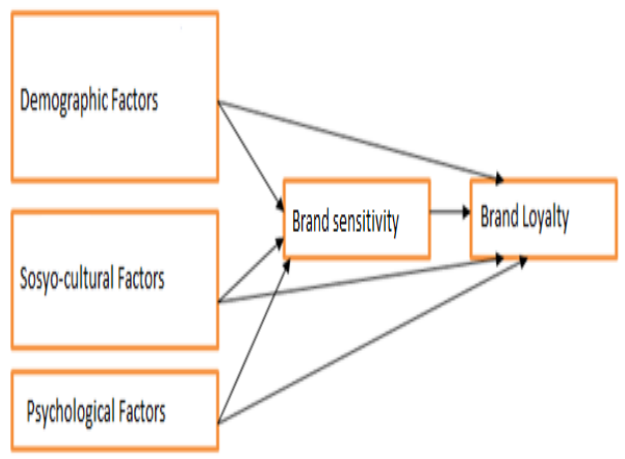

A questionnaire was used as data collection method. The questionnaire consists of two parts. In the first part, questions about demographic information were asked. In the second part, 57 questions were asked to determine the factors affecting brand loyalty and brand sensitivity of young people. Convenience sampling method was used in the research.

The sample group of our work consists of students from a high school age in a district in the Southeast Anatolian Region. For this reason, the sample group consisted of 350 students from female vocational and male high school. However, the number of analyzable questionnaires dropped to 338 after removal of inappropriate, inadequately answered questionnaires. In order to be able to apply the questionnaire to the schools, permission letters were written to the school directorates. The questionnaire was conducted under the supervision of the course teachers with our own participation.

\section{B. Data Collection and Research Hypothesis}

The scale used in this study was taken from a doctoral dissertation in Erciyes University, Institute of Social Sciences, Department of Business Administration, Department of Production Management and Marketing Science (Sönmez, 2009).

The hypotheses formed in the light of the stated purpose and theoretical explanations are as follows:

$\mathrm{H}_{1 \mathrm{a}}$ : There is a significant difference between age and brand sensitivity in a positive direction.

$\mathrm{H}_{1 \mathrm{~b}}$ : There is a significant difference between gender and brand sensitivity in a positive direction.

$\mathrm{H}_{1 \mathrm{c}}$ : There is a significant difference between class level and brand sensitivity in a positive direction.

$\mathrm{H}_{1 \mathrm{~d}}$ : There is a significant difference between father's education and brand sensitivity in a positive direction.

$\mathrm{H}_{1 \mathrm{e}}$ : There is a significant difference between mother's education and brand sensitivity in a positive direction.

$\mathrm{H}_{2 \mathrm{a}}$ : There is a significant difference between age and brand loyalty in a positive direction. 
$\mathrm{H}_{2 b}$ : There is a significant difference between gender and brand loyalty in a positive direction.

$\mathrm{H}_{2 \mathrm{c}}$ : There is a significant difference between class level and brand loyalty in a positive direction.

$\mathrm{H}_{2 \mathrm{~d}}$ : There is a significant difference between father's education and brand loyalty in a positive direction.

$\mathrm{H}_{2 \mathrm{e}}$ : There is a significant difference between mother's education and brand loyalty in a positive direction.

$\mathrm{H}_{3 \mathrm{a}}$ : Family affects brand sensitivity in a positive direction.

$\mathrm{H}_{3 \mathrm{~b}}$ : Peers affect brand sensitivity in a positive direction.

$\mathrm{H}_{3 \mathrm{c}}$ : KIA (Mass media) affects brand sensitivity in a positive direction.

$\mathrm{H}_{3 \mathrm{~d}}$ : Social class affects brand sensitivity in a positive direction.

$\mathrm{H}_{4 \mathrm{a}}$ : Family affects brand loyalty in a positive direction.

$\mathrm{H}_{4 b}$ : Peers affects brand loyalty in a positive direction.

$\mathrm{H}_{4 \mathrm{c}}$ : KIA (Mass media) affects brand loyalty in a positive direction.

$\mathrm{H}_{4 \mathrm{~d}}$ : Social class affects brand loyalty in a positive direction.

$\mathrm{H}_{5 \mathrm{a}}$ : Psychological factors affect brand sensitivity in a positive direction.

$\mathrm{H}_{5 b}$ : Psychological factors affect brand loyalty in a positive direction.

$\mathrm{H}_{6}$ : Brand sensitivity affects brand loyalty in a positive direction

\section{RESEARCH FINDINGS}

\section{A. Demographic Findings}

When the information on the demographic characteristics of the participants are examined, it is seen that $50.3 \%$ of the participants are male and $49.7 \%$ are female. When the distribution of participants by age is examined, it is seen that $57.1 \%$ is over 15 years old and $42.9 \%$ is 15 years old and under 15 years old. Information on demographic characteristics is shown in more detail on the table. When the table is examined, it is seen that $57.7 \%$ of the participants are 9 th graders, $13 \%$ are 10 th graders, $21.3 \%$ are 11 th graders and $8 \%$ are 12 th graders. In addition, when the education level of the fathers is examined, $38.5 \%$ of them are secondary school and $34.9 \%$ are primary school graduates; when the education level of the mothers is examined, it is seen that $52.4 \%$ of them did not go to the school. In addition, at the beginning of the study, reservecode operations were performed and MD2, MD3, MD16, PF9, FAMIL5, and KIA6 questions were removed from the analysis since they decrease reliablity. MD4, MD6, MD7, MB3, PF1, PF2, and KIAS2 questions were removed from the analysis because the factor load was low in the results of the exploratory factor analysis.
Table 1: Demographic Factors

\begin{tabular}{|c|c|c|c|}
\hline $\begin{array}{l}\text { Demographic } \\
\text { Factors }\end{array}$ & & $\mathrm{N}$ & $\%$ \\
\hline \multirow{2}{*}{ Gender } & Male & 170 & 50,3 \\
\hline & Female & 168 & 49,7 \\
\hline \multirow{2}{*}{ Age } & $15>$ & 193 & 57,1 \\
\hline & $15 \leq$ & 145 & 42,9 \\
\hline \multirow{4}{*}{ Class } & 9 & 195 & 57,7 \\
\hline & 10 & 44 & 13,0 \\
\hline & 11 & 72 & 21,3 \\
\hline & 12 & 27 & 8,0 \\
\hline \multirow{6}{*}{$\begin{array}{l}\text { Your father's } \\
\text { education }\end{array}$} & $\begin{array}{l}\text { Did not go } \\
\text { to the school }\end{array}$ & 34 & 10,1 \\
\hline & $\begin{array}{l}\text { Primary } \\
\text { school }\end{array}$ & 118 & 34,9 \\
\hline & Middle & 130 & 38,5 \\
\hline & School & & \\
\hline & High school & 45 & 13,3 \\
\hline & University & 11 & 3,3 \\
\hline \multirow{5}{*}{$\begin{array}{l}\text { Education of } \\
\text { the mother }\end{array}$} & $\begin{array}{l}\text { Did not go } \\
\text { to the school }\end{array}$ & 177 & 52,4 \\
\hline & $\begin{array}{l}\text { Primary } \\
\text { school }\end{array}$ & 99 & 29,3 \\
\hline & $\begin{array}{l}\text { Middle } \\
\text { School }\end{array}$ & 54 & 16,0 \\
\hline & High school & 8 & 2,4 \\
\hline & University & - & - \\
\hline
\end{tabular}

In addition, when crombach's alpha values of the variables are examined, it is found that brand sensitivity variable is 0.85 , brand loyalty variable is 0.72 , family variable is 0.73 , peer variable is 0.71 , mass media variable is 0.73 , social class variable is 0.71 and psychological factors variable is 0,76 . Kurtosis and skewness values show normal distribution of data and it is possible to apply parametric tests. The aggregate reliability values of the variables are above 0.70 , that is, the reliability is good. When we look at the results of exploratory factor analysis, factor loads are good because they are over 0.50 . In the direction of confirmatory factor analysis results, model adaptation is very good. $\left(\chi^{2} / d f ; 1,731\right.$, RMSEA:0.047, NFI: 0.714, CFI:0.853, IFI: 0.856, GFI; 0,830)

\section{B. Hypothesis Tests}

Hypothesis test can be summarised as follows;

Table 2: $T$ Test Reasults

\begin{tabular}{|c|c|c|c|c|c|c|c|}
\hline \multicolumn{3}{|c|}{ Değişkenler } & $\mathrm{N}$ & A.O & S.S. & $\mathbf{t}$ & P(sig.) \\
\hline \multirow{4}{*}{ Age } & \multirow{2}{*}{ MD } & $15<$ & 193 & 3,07 & 0,93 & \multirow{2}{*}{$\begin{array}{c}- \\
0,893\end{array}$} & \multirow{2}{*}{0,372} \\
\hline & & $15 \geq$ & 145 & 3,16 & 0,86 & & \\
\hline & \multirow{2}{*}{ MB } & $15<$ & 193 & 2,70 & 0,75 & \multirow{2}{*}{$\begin{array}{c}- \\
0,564 \\
\end{array}$} & \multirow{2}{*}{0,573} \\
\hline & & $15 \geq$ & 145 & 2,74 & 0,75 & & \\
\hline \multicolumn{3}{|c|}{ Değişkenler } & $\mathrm{N}$ & A.O & S.S. & $\mathbf{t}$ & P(sig.) \\
\hline \multirow{4}{*}{ Gender } & MD & Male & 170 & 3,17 & 0,87 & \multirow{2}{*}{1,173} & \multirow{2}{*}{0,242} \\
\hline & MD & Female & 168 & 3,05 & 0,93 & & \\
\hline & \multirow{2}{*}{ MB } & Male & 170 & 2,73 & 0,72 & \multirow{2}{*}{0,211} & \multirow{2}{*}{0,833} \\
\hline & & Female & 168 & 2,71 & 0,78 & & \\
\hline
\end{tabular}

In the study, T and Anova tests were applied to measure the relationship between demographic characteristics and brand loyalty and brand sensitivity. First of all, the $t$ test was used to determine whether there was a significant difference between the gender of the participants and the factors and between the ages of the participants and the factors. $T$ test results are shown on the table in detail. According to the results of $t$ test given in the table, it is seen that there is no significant difference between age and brand sensitivity ( $\mathrm{p}$ : 0,372 ) and there is no significant difference between gender 
and brand sensitivity (p: 0,242). Moreover, it was seenn that there was no significant difference between age and brand loyalty in a positive direction ( $\mathrm{p}$ : 0,573 ) and no significant difference between gender and brand loyalty in a positive direction (p: 0,833). "H1a: There is a significant difference between age and brand sensitivity in a positive direction." " $\mathrm{H}_{1 b}$ : There is a significant difference between gender and brand sensitivity in a positive direction." " $\mathrm{H}_{2 \mathrm{a}}$ : There is a significant difference between age and brand loyalty." " $\mathrm{H}_{2 \mathrm{~b}}$ : There is a significant difference between gender and brand loyalty in a positive direction " hypotheses have not been accepted.

\section{Anova Analysis Results}

Brand Sensitivity Anova test results can be summarised as follows;

Table 3: Brand Sensitivity Anova Test Analysis Results

\begin{tabular}{|c|c|c|c|c|c|c|c|}
\hline Factors & MD & $\mathrm{N}$ & A.O & $\begin{array}{l}\text { S. } \\
\text { D. }\end{array}$ & $\mathrm{F}$ & $\begin{array}{l}\mathrm{p} \\
\text { (sig. }\end{array}$ & $\begin{array}{l}\text { TUKE } \\
\text { Y HSD }\end{array}$ \\
\hline \multirow{4}{*}{ Class } & 9 & $\begin{array}{l}19 \\
5\end{array}$ & 3,09 & $\begin{array}{l}0,9 \\
8\end{array}$ & \multirow{4}{*}{$\begin{array}{l}1, \\
5\end{array}$} & \multirow{4}{*}{, 21} & \multirow{4}{*}{-} \\
\hline & 10 & 44 & 3,24 & $\begin{array}{l}0,8 \\
6\end{array}$ & & & \\
\hline & 11 & 72 & 3,20 & $\begin{array}{l}0,7 \\
9\end{array}$ & & & \\
\hline & 12 & 27 & 2,81 & $\begin{array}{l}0,6 \\
2\end{array}$ & & & \\
\hline \multirow{5}{*}{$\begin{array}{l}\text { Father } \\
\text { educatio } \\
n\end{array}$} & $\begin{array}{l}\text { Did not } \\
\text { go to the } \\
\text { school }\end{array}$ & 34 & 2,82 & $\begin{array}{l}1,0 \\
9\end{array}$ & \multirow{5}{*}{$\begin{array}{l}2, \\
8\end{array}$} & \multirow{5}{*}{,02 } & \multirow{5}{*}{$\begin{array}{l}\text { Did not } \\
\text { go to } \\
\text { the } \\
\text { school / } \\
\text { Middle } \\
\text { School }\end{array}$} \\
\hline & $\begin{array}{l}\text { Primary } \\
\text { school }\end{array}$ & $\begin{array}{l}11 \\
8\end{array}$ & 2,98 & $\begin{array}{l}0,9 \\
8\end{array}$ & & & \\
\hline & $\begin{array}{l}\text { Middle } \\
\text { School }\end{array}$ & $\begin{array}{l}13 \\
0\end{array}$ & 3,28 & $\begin{array}{l}0,7 \\
8\end{array}$ & & & \\
\hline & $\begin{array}{l}\text { High } \\
\text { school }\end{array}$ & 45 & 3,15 & $\begin{array}{l}0,8 \\
2\end{array}$ & & & \\
\hline & $\begin{array}{l}\text { Universit } \\
\mathrm{y}\end{array}$ & 11 & 3,32 & $\begin{array}{l}0,7 \\
2 \\
\end{array}$ & & & \\
\hline \multirow{5}{*}{$\begin{array}{l}\text { Maternal } \\
\text { educatio } \\
\mathrm{n}\end{array}$} & $\begin{array}{l}\text { Did not } \\
\text { go to the } \\
\text { school }\end{array}$ & $\begin{array}{l}17 \\
7\end{array}$ & 3,00 & $\begin{array}{l}0,9 \\
5\end{array}$ & \multirow{5}{*}{$\begin{array}{l}2 \\
9\end{array}$} & \multirow{5}{*}{,03 } & \multirow{5}{*}{$\begin{array}{l}\text { Did not } \\
\text { go to } \\
\text { the } \\
\text { school / } \\
\text { Middle } \\
\text { School }\end{array}$} \\
\hline & $\begin{array}{l}\text { Primary } \\
\text { school }\end{array}$ & 99 & 3,15 & $\begin{array}{l}0,8 \\
3\end{array}$ & & & \\
\hline & $\begin{array}{l}\text { Middle } \\
\text { School }\end{array}$ & 54 & 3,40 & $\begin{array}{l}0,8 \\
2\end{array}$ & & & \\
\hline & $\begin{array}{l}\text { High } \\
\text { school }\end{array}$ & 8 & 2,97 & $\begin{array}{l}1,0 \\
1\end{array}$ & & & \\
\hline & $\begin{array}{l}\text { Universit } \\
\mathrm{y}\end{array}$ & - & - & - & & & \\
\hline
\end{tabular}

Brand loyalty Anova test results can be summarised as follows;

Table 4: Brand Loyalty Anova Test Analysis Results

\begin{tabular}{|c|c|c|c|c|c|c|c|}
\hline Factors & MD & $\mathbf{N}$ & A.O. & $\begin{array}{l}\text { S. } \\
\text { D. }\end{array}$ & $\mathbf{F}$ & $\begin{array}{l}\text { p } \\
\text { (si } \\
\text { g.) }\end{array}$ & $\begin{array}{l}\text { TUKE } \\
\text { Y HSD }\end{array}$ \\
\hline \multirow{4}{*}{ Class } & 9 & $\begin{array}{l}19 \\
5\end{array}$ & 2,67 & 0,8 & \multirow{4}{*}{2,1} & \multirow{4}{*}{,09 } & \multirow{4}{*}{-} \\
\hline & 10 & 44 & 2,88 & 0,6 & & & \\
\hline & 11 & 72 & 2,81 & 0,6 & & & \\
\hline & 12 & 27 & 2,49 & 0,6 & & & \\
\hline \multirow{3}{*}{$\begin{array}{l}\text { Father } \\
\text { educatio } \\
n\end{array}$} & $\begin{array}{l}\text { Did not go } \\
\text { to the school }\end{array}$ & 34 & 2,55 & $\begin{array}{l}0,8 \\
5\end{array}$ & \multirow{3}{*}{2,3} & \multirow{3}{*}{, 05} & \multirow{3}{*}{-} \\
\hline & $\begin{array}{l}\text { Primary } \\
\text { school }\end{array}$ & $\begin{array}{l}11 \\
8\end{array}$ & 2,60 & $\begin{array}{l}0,7 \\
3\end{array}$ & & & \\
\hline & $\begin{array}{l}\text { Middle } \\
\text { School }\end{array}$ & $\begin{array}{l}13 \\
0\end{array}$ & 2,82 & $\begin{array}{l}0,7 \\
2\end{array}$ & & & \\
\hline
\end{tabular}

\begin{tabular}{|c|c|c|c|c|c|c|c|}
\hline & High school & 45 & 2,79 & 0,7 & & & \\
\hline & University & 11 & 3,03 & $\begin{array}{l}0,5 \\
8\end{array}$ & & & \\
\hline \multirow{5}{*}{$\begin{array}{l}\text { Materna } \\
1 \\
\text { educatio } \\
\mathrm{n}\end{array}$} & $\begin{array}{l}\text { Did not go } \\
\text { to the school }\end{array}$ & $\begin{array}{l}17 \\
7\end{array}$ & 2,67 & $\begin{array}{l}0,7 \\
4 \\
\end{array}$ & \multirow{5}{*}{$\begin{array}{l}1,2 \\
88\end{array}$} & \multirow{5}{*}{$\begin{array}{l}, 27 \\
8\end{array}$} & \multirow{5}{*}{ - } \\
\hline & $\begin{array}{l}\text { Primary } \\
\text { school }\end{array}$ & 99 & 2,69 & $\begin{array}{l}0,7 \\
8\end{array}$ & & & \\
\hline & $\begin{array}{l}\text { Middle } \\
\text { School }\end{array}$ & 54 & 2,88 & $\begin{array}{l}0,7 \\
2\end{array}$ & & & \\
\hline & High school & 8 & 2,90 & $\begin{array}{l}0,7 \\
0\end{array}$ & & & \\
\hline & University & - & - & - & & & \\
\hline
\end{tabular}

ANOVA test, which was conducted to determine whether there is a significant difference between brand sensitivity and brand loyalty, and class, father's education and mother's education factors, is shown in the table 3 and 4 . According to the results obtained, it is seen that there is a significant difference between the father 's educational status and brand sensitivity in a positive direction (p: 0,026) and it is found that this difference is between the university, and high school and secondary school education. It is seen that children whose fathers have got university education (ao: 3,32) have more brand sensitivty than children whose fathers have got high school (ao: 3,15) and secondary school (ao: 3,28) education. In addition, it is found that there is a significant difference between mother's educational status and brand sensitivity in a positive direction ( $\mathrm{p}: 0,036$ ), and this difference is found to be between secondary school, and primary school and nonschool education. It is seen that children whose mothers have got secondary school education (ao: 3,40 ) have more brand sensitivty than children whose mothers have got primary school education (ao: 3,15) and have not got any school education (ao: 3,00). Therefore, it can be said that young people whose fathers have got university education and whose mother have got secondary school education give more importance to brand sensitivity than others. In this regard, "H1d: There is a significant difference between father's education and brand sensitivity in a positive direction." and "H1e: There is a significant difference between mother's education and brand sensitivity in a positive direction." hypotheses have been accepted. However, " H1c: There is a significant difference between class level and brand sensitivity in a positive direction." $\mathrm{H} 2 \mathrm{c}$ : There is a significant difference between class level and brand loyalty in a positive direction." "H2d: There is a significant difference between father's education and brand loyalty in a positive direction." and "H2e: There is a significant difference between mother's education and brand loyalty in a positive direction." hypotheses have not been accepted.

\section{Correlation and Regression Results}

Correlation analysis and interpretations can be summarised as follows;

\begin{tabular}{|c|c|c|c|c|c|c|c|c|}
\hline & & $\begin{array}{l}\text { MD } \\
\text { ort }\end{array}$ & $\begin{array}{l}\text { MB } \\
\text { ort }\end{array}$ & $\begin{array}{l}\text { Fami } \\
\text { lyort }\end{array}$ & $\begin{array}{l}\text { Kiao } \\
\mathrm{rt}\end{array}$ & $\begin{array}{l}\text { Ark } \\
\text { ort }\end{array}$ & $\begin{array}{l}\text { PFor } \\
\mathrm{t}\end{array}$ & Sort \\
\hline \multirow[t]{3}{*}{$\begin{array}{l}\text { MD } \\
\text { ort }\end{array}$} & \multirow{3}{*}{$\begin{array}{l}\text { PearsonCo } \\
\text { rrelation } \\
\text { Sig. (2- } \\
\text { tailed) } \\
\mathrm{N}\end{array}$} & \multirow[t]{2}{*}{1} & $\begin{array}{l}, 462 \\
(* *)\end{array}$ & $\begin{array}{l}, 355( \\
* *)\end{array}$ & $\begin{array}{l}, 406 \\
(* *)\end{array}$ & $\begin{array}{l}, 323 \\
(* *)\end{array}$ & $\begin{array}{l}, 500 \\
(* *)\end{array}$ & $\begin{array}{l}, 285 \\
(* *)\end{array}$ \\
\hline & & &, 000 &, 000 & 000 & ,000 & ,000 & ,000 \\
\hline & & 338 & 338 & 338 & 338 & 338 & 338 & 338 \\
\hline \multirow[t]{3}{*}{$\begin{array}{l}\text { MB } \\
\text { ort }\end{array}$} & \multirow{3}{*}{$\begin{array}{l}\text { PearsonCo } \\
\text { rrelation } \\
\text { Sig. (2- } \\
\text { tailed) } \\
\mathrm{N}\end{array}$} & $\begin{array}{l}, 462 \\
(* *)\end{array}$ & 1 & $\begin{array}{l}, 335( \\
* *)\end{array}$ & $\begin{array}{l}, 529 \\
(* *)\end{array}$ & $\begin{array}{l}, 458 \\
(* *)\end{array}$ & $\begin{array}{l}, 642 \\
(* *)\end{array}$ & $\begin{array}{l}, 269 \\
(* *)\end{array}$ \\
\hline & &, 000 & & ,000 & ,000 & ,000 &, 000 & ,000 \\
\hline & & 338 & 338 & 338 & 338 & 338 & 338 & 338 \\
\hline
\end{tabular}




\begin{tabular}{|c|c|c|c|c|c|c|c|c|}
\hline \multirow[t]{3}{*}{$\begin{array}{l}\text { Ail } \\
\text { eort }\end{array}$} & $\begin{array}{l}\text { PearsonCo } \\
\text { rrelation }\end{array}$ & $\begin{array}{l}, 355 \\
(* *)\end{array}$ & $\begin{array}{l}, 335 \\
(* *)\end{array}$ & 1 & $\begin{array}{l}, 277 \\
(* *)\end{array}$ & $\begin{array}{l}, 390 \\
(* *)\end{array}$ & $\begin{array}{l}, 302 \\
(* *)\end{array}$ & $\begin{array}{l}, 169 \\
(* *)\end{array}$ \\
\hline & $\begin{array}{l}\text { Sig. (2- } \\
\text { tailed) }\end{array}$ & ,000 & ,000 & & ,000 & ,000 & , 000 & ,002 \\
\hline & $\mathrm{N}$ & 338 & 338 & 338 & 338 & 338 & 338 & 338 \\
\hline \multirow[t]{3}{*}{$\begin{array}{l}\text { Kia } \\
\text { ort }\end{array}$} & $\begin{array}{l}\text { PearsonCo } \\
\text { rrelation }\end{array}$ & $\begin{array}{l}, 406 \\
(* *)\end{array}$ & $\begin{array}{l}, 529 \\
(* *)\end{array}$ & $\begin{array}{l}, 277( \\
* *)\end{array}$ & 1 & $\begin{array}{l}, 407 \\
(* *)\end{array}$ & $\begin{array}{l}, 563 \\
(* *)\end{array}$ & $\begin{array}{l}182 \\
(* *)\end{array}$ \\
\hline & $\begin{array}{l}\text { Sig. (2- } \\
\text { tailed) }\end{array}$ & , 000 & , 000 & ,000 & & ,000 & , 000 & ,001 \\
\hline & $\mathrm{N}$ & 338 & 338 & 338 & 338 & 338 & 338 & 338 \\
\hline \multirow[t]{3}{*}{$\begin{array}{l}\text { Ark } \\
\text { ort }\end{array}$} & $\begin{array}{l}\text { PearsonCo } \\
\text { rrelation }\end{array}$ & $\begin{array}{l}, 323 \\
(* *)\end{array}$ & $\begin{array}{l}, 458 \\
(* *)\end{array}$ & $\begin{array}{l}, 390( \\
* *)\end{array}$ & $\begin{array}{l}, 407 \\
(* *)\end{array}$ & 1 & $\begin{array}{l}, 411 \\
(* *)\end{array}$ & $\begin{array}{l}, 175 \\
(* *)\end{array}$ \\
\hline & $\begin{array}{l}\text { Sig. (2- } \\
\text { tailed) }\end{array}$ & ,000 & ,000 & ,000 & ,000 & & ,000 &, 001 \\
\hline & $\mathrm{N}$ & 338 & 338 & 338 & 338 & 338 & 338 & 338 \\
\hline \multirow[t]{3}{*}{$\begin{array}{l}\mathrm{PFo} \\
\mathrm{rt}\end{array}$} & $\begin{array}{l}\text { PearsonCo } \\
\text { rrelation }\end{array}$ & $\begin{array}{l}, 500 \\
(* *)\end{array}$ & $\begin{array}{l}, 642 \\
(* *)\end{array}$ & $\begin{array}{l}, 302( \\
* *)\end{array}$ & $\begin{array}{l}, 563 \\
(* *)\end{array}$ & $\begin{array}{l}, 411 \\
(* *)\end{array}$ & 1 & $\begin{array}{l}, 251 \\
(* *)\end{array}$ \\
\hline & & , 000 & ,000 & , 000 & ,000 & 000 & &, 000 \\
\hline & $\mathrm{N}$ & 338 & 338 & 338 & 338 & 338 & 338 & 338 \\
\hline \multirow{3}{*}{$\begin{array}{l}\text { Sor } \\
t\end{array}$} & $\begin{array}{l}\text { PearsonCo } \\
\text { rrelation }\end{array}$ & $\begin{array}{l}, 285 \\
(* *)\end{array}$ & $\begin{array}{l}, 269 \\
(* *)\end{array}$ & $\begin{array}{l}, 169( \\
* *)\end{array}$ & $\begin{array}{l}, 182 \\
(* *)\end{array}$ & $\begin{array}{l}, 175 \\
(* *)\end{array}$ & $\begin{array}{l}, 251 \\
(* *)\end{array}$ & 1 \\
\hline & $\begin{array}{l}\text { Sig. (2- } \\
\text { tailed) }\end{array}$ & , 000 & , 000 & ,002 & ,001 & ,001 & , 000 & \\
\hline & $\mathrm{N}$ & 338 & 338 & 338 & 338 & 338 & 338 & 338 \\
\hline
\end{tabular}

** Correlation is significant at the 0.01 level (2-tailed).

The hypotheses generated in the research were analyzed with correlation analysis and regression analysis. Correlation analysis results are given in detail in the table. According to the correlation analysis results shown in the table, there is a positive correlation between family, $355(* *)$, peers, 323 $(* *)$, social class, $285(* *)$, psychological factors, $500(* *)$ and brand sensitivity. It has also been found that there is a positive relationship between peers, $458(* *)$, mass media, $\left.529{ }^{* *}\right)$, social class, $\left.269{ }^{* *}\right)$, psychological factors, 642 $(* *)$ and brand loyalty. Brand loyalty also affects brand sensitivity positively.

\begin{tabular}{lllllllll}
\hline Variable & B & $\begin{array}{l}\text { Standar } \\
\text { d error }\end{array}$ & B & t & p & $\begin{array}{c}\text { Tol } \\
\text { eranc } \\
\text { e }\end{array}$ & VIF \\
\hline Constant &, 810 &, 195 & & 4,163 &, 000 & & \\
Family &, 181 &, 050 &, 181 & 3,642 &, 000 &, 815 & 1,22 \\
Peers &, 132 &, 055 &, 135 & 2,412 &, 016 &, 642 & 1,55 \\
Mass &, 042 &, 052 &, 043 & 0,811 &, 418 &, 720 & 1,38 \\
media(KIA) & & & & & & & \\
Psychological &, 341 &, 061 &, 316 & 5,546 &, 000 &, 620 & 1,61 \\
F. &, 118 &, 038 &, 143 & 3,059 &, 002 &, 924 & 1,08 \\
Social class & $\mathrm{R}^{2}=$, & $\Delta \mathrm{R}^{2}=, 32$ & \multicolumn{2}{c}{ DurbinWatson=1,8 } \\
R=,576 & 332 & 2 & 91 & & & & \\
$\mathrm{~F}_{(1,337)=32,954}$ & & $\mathrm{p}<$ & 0,000 & & & & & \\
\hline
\end{tabular}

Dependent Variable: Brand Sensitivity

\begin{tabular}{llllllll}
\hline \multicolumn{1}{c}{ Variable } & $\mathbf{B}$ & $\begin{array}{c}\text { Standar } \\
\text { d error }\end{array}$ & $\mathbf{B}$ & $\mathbf{t}$ & $\mathbf{p}$ & $\begin{array}{l}\text { Tolera } \\
\text { nce }\end{array}$ & $\mathbf{~ V I}$ \\
\hline $\begin{array}{l}\text { Constant } \\
\text { Family }\end{array}$ &, 535 &, 141 & & 3,80 &, 000 & & \\
$\begin{array}{l}\text { Peers } \\
\text { Mass }\end{array}$ &, 152 &, 036 &, 077 & 1,78 &, 075 &, 815 & 1,22 \\
$\begin{array}{c}\text { media(KIA) } \\
\text { Psychologi }\end{array}$ &, 132 &, 038 &, 187 & 3,83 &, 000 &, 642 & 1,55 \\
cal F. \\
$\begin{array}{c}\text { Social } \\
\text { class }\end{array}$
\end{tabular}

\begin{tabular}{|c|c|c|c|c|c|c|c|}
\hline Constant & 1,526 & ,130 & & $\begin{array}{l}11,69 \\
2\end{array}$ & $\begin{array}{l}, 00 \\
0\end{array}$ & & \\
\hline $\begin{array}{l}\text { M. } \\
\text { Sensitivity }\end{array}$ & ,384 & ,040 & ,462 & $43^{9,5}$ & $\begin{array}{l}, 00 \\
0\end{array}$ & 1,000 & $\begin{array}{l}1,00 \\
0\end{array}$ \\
\hline $\mathrm{R}=, 462$ & $\begin{array}{l}\mathrm{R}^{2}=, 2 \\
13\end{array}$ & $\Delta \mathrm{R}^{2}=, 211$ & \multirow{2}{*}{\multicolumn{5}{|c|}{$\begin{array}{l}\text { Durbin-Watson= } \\
1,742\end{array}$}} \\
\hline$F_{(1,337)}=91$, & & $\mathrm{p}<0,000$ & & & & & \\
\hline
\end{tabular}

\section{Dependent Variable: Brand Loyalty}

The results obtained from the correlation test for measuring research hypotheses partially confirm the suitability of using regression test for the purpose of study. The hypotheses to be measured are explained in the context of the regression test. The effects of variables on brand sensitivity and brand loyalty were tried to be determined by regression analysis. The results of the relevant hypotheses are shown in the table. When the results obtained are examined, it is found that family variables affect brand sensitivity positively (p: 0,000$)$, peers affect brand sensitivity positively ( $p: 0.016$ ), social class affects brand sensitivity positively (p: 0.002), and psychological factors affect brand sensitivity positively (p: $0,000)$, but mass media do not affect brand sensitivity positively (p: 0.418).

In addition to this, it is seen that peers affect brand loyalty positively (p: 0,000), mass media affect brand loyalty positively (p: 0,001 ), psychological factors affect brand loyalty positively (p: 0,000), and social class affect brand loyalty positively ( $\mathrm{p}: 0.032$ ), but family variable does not affect brand loyalty positively. It is also seen that brand sensitivity affects brand loyalty positively (p: 0,000$)$.

\section{CONCLUSION}

Businesses attach great importance to the brand they create. The birth and continuity of the brands require great effort. In order for a brand to survive, it must have different characteristics from other brands. This means it is necessary to have an awareness of this brand. From this point of view, each firm should clearly state which aspects of its own brand are superior to other brands. In doing so, the mass it appeals to, and the way of reaching this mass is very important. To be permanent, a brand must be promoted very well. Today, young people aim to create awareness to be different. Of course, they do this through featured brands. Addressing young people is very important because a brand that is popular among young people is a step ahead in terms of being long-term. With the rapid growth of technology, everything is now with us. So the companies should use it well. It is very important that a product is sold on the internet and spread through communication networks. A product spreads very quickly among young people. The effort to get the product he sees in his friend is seen in most young people. Advertising is also a great asset in product promotion. A product advertised by a famous person on television attracts the attention of young people very quickly. Of course, there are many factors for these brands to be able to hold on.

This study was conducted to analyze the brand loyalty and brand sensitivity of students from vocational school for girls and male high school in a district in the Southeast Anatolian region. It has been found that there is no significant difference between age (p: 0.372) and gender (p: 0.224), and brand sensitivity, no significant difference between age ( $p: 0,573$ ) and gender (p: 0,833), and brand loyalty, no significant difference between class level and brand sensitivity (p: 0,217$)$ and brand loyalty (p: 0,095). Although fathers' educational 
status has positive effects on brand sensitivity (p:0, 026), it does not have positive effects on brand loyalty (p: 0,054). In addition, mothers' educational status has positive effects on brand sensitivity (p: 0,036), it does not have positive effects on brand loyalty (p: 0,278). In addition, while family affects brand sensitivity positively (p: 0,000), it does not affect brand loyalty positively ( $p: 0,75)$. It has been observed that the mass media have the opposite situation. In other words, while mass media do not affect brand sensitivity positively (p: 0,418), it affects brand loyalty positively (p: 0.001).

Sönmez (2009) emphasize in his study that psychological factors are the most important factor affecting brand loyalty and brand sensitivity positively. In our study, parallel to this, the results show that psychological factors affect both brand sensitivity and brand loyalty positively. Both studies point out that family does not affect brand loyalty, but affects brand sensitivity positively, and peers affect both brand sensitivity and brand loyalty positively. In addition, while in Sonmez's study, mothers' educational status affects brand loyalty positively, mother's educational status affects brand sensitivity positively in our study.

Doğan (2012) states in his study that brand loyalty does not differ according to gender, but it differs according to age. Mızrakçı (2011) also explaine that the gender factor is not very important in brand loyalty. Parallel to these, in our study, it is concluded that neither gender nor age affects brand loyalty positively.

It may be suggested that new researches be done in different cities, with different age groups and different income levels, including even in-house siblings, in different products.

\section{REFERENCES}

[1] N. Allen, J.,and J. P. Meyer, "The measurement and antecedents of affective, continuance and normative commitment to the organization," Journal Of Occupational And Organizational Psychology, 63(1), pp. 1-18.1990.

[2] T. Ak, "Marka Yönetimi Ve Tüketici Karar Sürecine Etkileri," Yayımlanmamış Yüksek Lisans Tezi, Karamanoğlu Mehmet Bey Üniversitesi, Karaman. 2009.

[3] T. Ambler, and C. Styles, "Brand Development Versus New Product Development: Toward a Process Model of Extension Decisions," Journal Of Product \&Brand Management. 6 (4), 1997, pp. 222-234.

[4] A. Ayhan, “ Yaşamdan Örneklerle Yedi Adımda Markalaşma," Sistem Yayıncılık, Brand Management MKT 505, 2012,

[5] B. Balıkçıŏlu, and S. Oflazoğlu, "Marka Evangelizmi, BenlikMarka İmajı Uyumu ve Marka Sadakati İlişkisi Üzerine Ampirik Bir Araştırma, Tüketici ve Tüketim Araştırma Dergisi, 7 (2), Aralık, 2015, pp. 19-45.

[6] T. Dereli, and A. Baykasoğlu, “Toplam Marka Yönetimi,” İstanbul Hayat Yayınları, 2007, pp. 241, 325.

[7] T. K. Devrani, "Marka Sadakati Öncülleri: Çalışan Kadınların Kozmetik Ürün Tüketimi Üzerine Bir Çalışma,” Süleyman Demirel Üniversitesi Íktisadi ve İdari Bilimler Dergisi, 14 (3), 2009, pp. $407-$ 421.

[8] M. Doğan, "Tüketicilerin Markaya Duyduğu Güven ve Marka Bağlılığı İlişkisi," Yayınlanmamış Yüksek Lisans Tezi, Karabük Üniversitesi, Karabük, 2012.

[9] M. K. Ercan, M. Öztürk, K. Demirgüneș, E.S. Başcı, and İ. Küçükkaplan, "Marka Değerinin Tespiti. Ankara: İstanbul Menkul Klymetler Borsası, Aralık. 2010

[10] N. Eriș, and Ș. Kutlu, "Marka Bağlılığ1 Yaratmada Müșteri İlișkileri Yönetimi,” Ankara Üniversitesi Sosyal Bilimler Enstitüsü İşletme Ana Bilim Dall, Ankara, Mayıs 2007, pp. 26.

[11] O. Eru, "Marka Bağlılığını Etkileyen Faktörler: Adnan Menderes Üniversitesi Öğrencileri Üzerinde Bir Uygulama," Yayınlanmamış Yüksek Lisans Tezi, Adnan Menderes Üniversitesi, Aydın, 2007.

[12] İ. B. Ilıcalı, Ö. Yönet, Ş. Şahin, and H.K. Suher, "Algılanan Marka Benzerliğinin; Marka Sadakati, Marka Tatmini ve Servis Kalitesi ile
Olan İlişkisi: Kargo Kategorisine Yönelik Bir Araştırma," Marmara Üniversitesi Öneri Dergisi, 2 (46), 2016, pp. 295-319.

[13] K. Keller, (1988). Strategic Brand Management Building, Measuring And Managing Brand Equity. Global Edition, Fourth Edition, 590.

[14] Ü. Kement, and S. Çavuşoğlu, “ Hafizaya Yönelik Müşteri Deneyimlerinin Müşteri Sadakatine Etkisi: Yeşil Oteller Örneği,” Uluslararası Sosyal ve Eğitim Bilimleri Dergisi, 4(8), 2017, pp. 172194.

[15] R. Leahy, "Brand Loyalty in Fast Moving Consumer Good Markets: The Role of Bonds," International Journal of Business And Management, 3 (12), 2008, pp. 7-19.

[16] M. Mellens, M.G. Dekımpe, and J.B.E.M. Steenkamp, "A Review of Brand -Loyalty Measures in Marketing," Tijdschrift Voor Economie En Management. XLI (4), 1996, pp. 507-533.

[17] Ş. Mizırakçı, "Gençlerin Markaya Duyduğu Güven ve Memnuniyetin Marka Bağlılığı Üzerine Etkileri-KTÜ Örneği,” Yayınlanmamış Yüksek

[18] B. Schmitt, and A. Simonson," "Pazarlama Estetiği. Marka, Kimlik ve İmajın Stratejik Yönetimi. (Çev: Zelal Ayman), Sistem Yayıncılık: 245, Haziran, 2000.

[19] E. Sönmez, “ Giyimde Marka Bă̆hlliğg ve Marka Duyarlılı̆̆g: Gençler Üzerine Bir Araştırma." Yayınlanmamış Doktora tezi, Erciyes Üniversitesi, Kayseri, 2009.

[20] Ö. Şahin, “ Marka Sadakatini Etkileyen Faktörlerin Belirlenmesi ve Tüketiciler Üzerinde Bir Uygulama.” Yayınlanmamış Yüksek Lisans Tezi, Çukurova Üniversitesi, Adana. 2007.

[21] A.S. Taylor, K. Celuch, and S. Goodwin, “ The Importance of Brand Equity to Customer Loyalty.Journal of Product \&Brand Management, 13 (4), 2004, pp. 217-227.

[22] S. Ünal, A. Deniz, ve Can P., “ Marka Bağlılığı ve Kişisel Değerler Açısından Pazar Bölümleme.”'Iktisadi ve Ídari Bilimler Dergisi. 22 (1), Ocak, 2008, pp. 211-237.

[23] R. V. Vliet, “ Brand Sensitivity: A Case for Shoes." Master thesis, 47, 2010.

[24] L. Wood, "Brands and Brand Equity: Definition and Management." Management Decision, 38(9), 2000, pp. 662-669.

[25] TDK, "Markaların Korunması Hakkındaki 556 Sayılı Kanun Hükmündeki Kararnamenin 5. Maddesi.” www.tdk.gov.tr.2017 (Erişim Tarihi: 05.04.2017).

[26] D. Yadin, “ The International Dictionary of Marketing. "KoganPage, 442. 2002.

[27] O. Yıldız, “ Gençliğin Markaya Duyduğu Güven Marka Sadakati İlişkisinin Belirlenmesi." Yayınlanmamış Yüksek Lisans Tezi, Çukurova Üniversitesi, Adana, 2006.

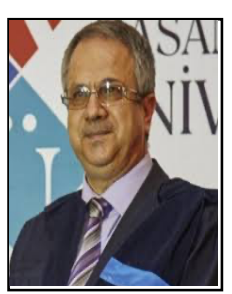

Assoc. Prof. Dr. Yakup DURMAZ:

License; Anadolu University

Department of Economics

Master: Kahraman Maraş Sütçü

İmam University, Business Administration

Department

PhD: İnönü University Marketing Department.

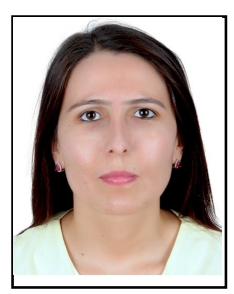

\section{Lecturer Özlem ÖZER:}

She was born in 1985 in Osmaniye. She completed her primary, secondary and high school education in Osmaniye. In 2010, she graduated from Konya Selçuk University Karaman Faculty of Economics and Administrative Sciences, Department of Business Administration. In 2012, she completed her master's degree in Business Administration at Kahramanmaraş Sütçü İmam University. In 2012, she started to work as a lecturer at Harran University Akçakale High School. She has been continuing her doctoral studies in Business Administration at Hasan Kalyoncu University since 2017. She teaches general accounting, corporate accounting, bank accounting, financial management, financial investment tools, general business, business and social security law at Harran University Akçakale High School. The main fields of study are; accounting, finance and business management. She speaks English fluently and is single. 


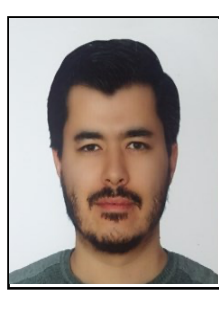

Lecturer Dr. Sinan ÇAVUŞOĞLU:

He was born in 1986 in Karapınar, Konya. He completed his primary school education in Konya, Secondary and high school education in Silifke district of Mersin. In 2008, he graduated from Bülent Ecevit University, Faculty of Economics and Administrative Sciences, Department of Business Administration. The same year, he started his post graduate education at Bülent Ecevit University, Department of Sales and Marketing. In 2010, he started to work as a lecturer at Bingöl University High School of Social Sciences. In 2019, he successfully completed his doctorate education at Hasan Kalyoncu University Social Sciences Institute Business Administration and received the title of "Doctor". He teaches marketing principles, sales management, E-commerce, international marketing, consumer behavior, entrepreneurship and accounting at Bingöl University Social Sciences HighSchool. The main fields of study are; consumer behavior, customer relationship management, tourism marketing, brand and leadership. Çavuşoğlu speaks English fluently and is married with one child. 